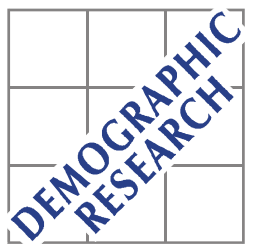

Demographic Research a free, expedited, online journal

of peer-reviewed research and commentary in the population sciences published by the Max Planck Institute for Demographic Research

Konrad-Zuse Str. 1, D-18057 Rostock · GERMANY

www.demographic-research.org

DEMOGRAPHIC RESEARCH

VOLUME 19 ARTICLE 41, PAGES 1513-1550

PUBLISHED 29 AUGUST 2008

http://www.demographic-research.org/Volumes/Vol19/41/

DOI: 10.4054/DemRes.2008.19.41

Research Article

Women's changing socioeconomic position and union formation in Spain and Portugal

Marta Domínguez-Folgueras

Teresa Castro-Martín

(c) 2008 Domínguez-Folgueras \& Castro-Martín.

This open-access work is published under the terms of the Creative Commons Attribution NonCommercial License 2.0 Germany, which permits use, reproduction \& distribution in any medium for non-commercial purposes, provided the original author(s) and source are given credit.

See http:// creativecommons.org/licenses/by-nc/2.0/de/ 


\section{Table of Contents}

1 Introduction 1514

$2 \quad$ Theoretical background and hypotheses 1517

3 Women's changing social and economic position in 1520

Spain and Portugal

$4 \quad$ Recent nuptiality trends 1525

$5 \quad$ Data and methods $\quad 1527$

$6 \quad$ Results 1529

6.1 Factors influencing women's transition to first union 1529

6.2 The changing effect of women's education and employment 1533 across cohorts

$\begin{array}{lll}7 & \text { Conclusion } & 1537\end{array}$

$8 \quad$ Acknowledgements 1539

$\begin{array}{ll}\text { References } & 1541\end{array}$

$\begin{array}{ll}\text { Appendix } & 1547\end{array}$ 


\title{
Women's changing socioeconomic position and union formation in Spain and Portugal
}

\author{
Marta Domínguez-Folgueras ${ }^{1}$ \\ Teresa Castro-Martín ${ }^{2}$
}

\begin{abstract}
Economic and sociological theories of marriage have long emphasized the impact of women's education and employment on union formation. In this study, we explore the relevance of the female economic independence hypothesis to explain women's patterns of entry into marriage and cohabitation in Portugal and Spain. In these two Southern European countries, gender equity has improved remarkably in the public sphere, but family relations remain structured along traditional gender roles. We focus on three indicators of women's autonomy: educational attainment, employment status, and having lived independently from the family of origin. The analysis is based on the Fertility and Family Surveys and discrete-time multinomial logistic regression models are used to estimate the odds of marrying, cohabiting or remaining single. The results suggest that whereas the effect of female education is consistent with the independence hypothesis, women's labour force participation encourages union formation, particularly among younger cohorts. Living independently from the family of origin reduces the likelihood of entering into marriage but increases considerably the odds of cohabiting.
\end{abstract}

\footnotetext{
${ }^{1}$ Dpt. of Political and Social Sciences, Universitat Pompeu Fabra, Barcelona. E-mail: marta.dominguez@upf.edu.

${ }^{2}$ Institute of Economics, Geography and Demography, CSIC (Spanish National Research Council), Madrid.

E-mail: tcastro@ieg.csic.es.
} 


\section{Introduction}

In recent decades, union formation patterns have undergone significant transformations in all Western societies (Billari 2005). Later and fewer marriages, increasing cohabitation, rising divorce and a growing proportion of children born and reared outside marriage are some of the features that have shaped the new context of partnerships. Marriage, which was once part of the natural progression into adulthood, has lost much of its centrality in structuring women's (and men's) adult lives.

Theoretical models of marriage have long emphasized the changing social and economic position of women as a key catalyst of these changes. Women's increasing education and earning power have been hypothesized as reducing the "gains" and desirability of marriage (Becker 1981). However, the economic independence hypothesis, as it is commonly referred to, has received only limited empirical support in micro-level analyses. Several studies have shown that women's higher educational attainment and greater economic resources, as measured by employment and earnings, have little effect on marriage formation or else a positive effect in a number of countries, such as the US (Oppenheimer and Lew 1995; Thornton et al. 1995; Goldstein and Kenny 2001; Sweeney 2002; Xie et al. 2003), the UK (Berrington and Diamond 2000), the Netherlands (Liefbroer and Corijn 1999), Sweden (Bracher and Santow 1998), Germany (Blossfeld and Huinink 1991) or Australia (Santow and Bracher 1994). In fact, empirical evidence consistent with the economic independence hypothesis has only been found in certain countries, such as Italy (Billari et al. 2002) or Japan (Ono 2003; Raymo 2003; Raymo and Iwasawa 2005). This pattern of cross-country variation has prompted scholars to look into the interplay of gender relations in the public and private domains as a conditioning factor of educated women's decisions regarding marriage. Educational attainment appears to deter marriage mostly in societies where improvements in women's economic opportunities have not been accompanied by an important reorganization of men's and women's responsibilities within the family, increasing the opportunity costs of union formation.

When the independence hypothesis was developed, marriage was the predominant form of conjugal union, but nowadays cohabitation provides an increasingly common pathway to marriage or an alternative to it. Compared to marriage, which typically carries with it strong implicit assumptions about gendered family roles, cohabitation is less institutionalized, and couples may feel freer to negotiate their relationship on an equal basis (Cunningham 2005). This type of union, with more flexible gender role expectations, is expected to be more attractive to educated women. Evidence in the literature, however, is not conclusive or uniform across countries. Although educational attainment tends to be associated with greater acceptance of untraditional familial behaviour and better educated women appear to have led the early growth in 
cohabitation, several studies have found a negative effect of educational attainment on cohabitation in the US (Thornton et al. 1995; Xie et al. 2003), although positive in Italy and Sweden (Goldscheider et al. 2001).

In this paper, we explore the relevance of the independence hypothesis in explaining women's patterns of entry into marriage and cohabitation in two Southern European countries, Portugal and Spain, which are characterized by recently achieved gender equality in the public sphere but asymmetrical gender roles within the family (Almeida and Wall 2001). During recent decades, both countries have undergone a profound process of modernization. Broad transformations in the economic, political and social fronts have brought about a radical change in the standard of living, life-style and attitudes of young generations. One of the most significant transformations has been the changing role of women, as reflected in their recently achieved parity with men in education and in their rapid incorporation into the labour force. Within the family, however, women remain primarily responsible for housework and caring activities. Norms and values concerning partnership formation and disruption have also undergone a profound change, and behaviours that were considered "immoral" only thirty years ago are nowadays widely accepted. Nevertheless, social attitudes have moved forward more rapidly than actual practices (Baizán et al. 2002), and the prevalence of new family forms, such as cohabiting unions, remains low in comparison to other European countries (Meil Landwerlin 2003; Heuveline and Timberlake 2004).

Early views of the second demographic transition assumed that the decline in fertility would go hand in hand with the pluralization of family forms (van de Kaa 1987). However, the emergence of lowest-low fertility in the early 1990s in Southern Europe (Kohler et al. 2002), the region with the least diversified family forms, questioned the initial assumption of convergence (Billari and Wilson 2001) and strengthened the view of path dependency (Blossfeld 2003). In order to explain the "paradox" of lowest-low fertility coexisting with traditional family patterns in Southern Europe (Dalla Zuanna and Micheli 2004), some scholars have emphasized the weakness of the welfare system and the important role of the family as a safety net (Jurado and Naldini 1996; Esping-Andersen 1999), the historical legacies of strong kinship ties (Reher 1998), high youth unemployment (Ahn and Mira 2001), tight housing markets (Holdsworth and Irazoqui 2002), and pressure from the parental family (Rosina and Fabroni 2004). Inconsistent gender relations in the public and private spheres have also been pointed out as a potential explanation for the concurrence of lowest-low fertility and traditional family forms. Chesnais (1996) and McDonald (2000) argue that the incoherence between high levels of gender equity in institutions that deal with people as individuals -such as the education system, the labour market and the political system and sustained gender inequality in institutions that deal with people as members of families and are still underpinned by the male breadwinner model - such as social 
services, government transfers or the family itself - leads to very low fertility. Gender equity arguments could be extended to explain the latest-late pattern of union formation in Southern Europe.

Although Southern European countries are usually portrayed as "traditional" in their family patterns, except for their lowest-low fertility, it is important to note that some important changes have been taking place recently. For instance, non-marital fertility, a behaviour that is typically linked to the second demographic transition, can no longer be labelled as marginal in Spain or Portugal. In 2006, 28.4\% of all births in Spain and 31.6\% in Portugal took place outside marriage. According to the FFS-1995, approximately one third of out-of-wedlock births corresponded to consensual unions in Spain, but this proportion is probably higher nowadays - in 2006, 94\% of non-marital births had registered the father's age, an indirect proxy for legal recognition. In Portugal, vital statistics show that $80 \%$ of non-marital births - and hence, $25 \%$ of all births - corresponded to cohabiting couples in 2006. Therefore, under the apparent surface of tradition and immobility in family forms, significant transformations are underway. Moreover, aggregate indicators usually employed to illustrate the European North-South divide in women's social and economic position are often misleading, because they do not take into account the large differences prevailing between coexisting cohorts (Fernández Cordón and Sgritta 2000). For instance, although women's education and labour force participation for the overall Spanish population are well below the EU average, when the comparison is restricted to the youngest cohorts, differentials disappear. For this reason, this paper will place special emphasis on intergenerational change. Since the educational and employment status of younger cohorts have changed dramatically, the impact of female economic independence on union formation is not likely to have remained unaltered.

The structure of the paper is as follows. We first conduct a brief review of the literature on the influence of women's autonomy on partnership formation decisions. We then describe women's changing position in Spain and Portugal, focusing on their educational attainment, labour force participation, attitudes and the household division of labour. Next, we review nuptiality trends and assess the prevalence of cohabitation based on the 2001 censuses. Finally, based on the Fertility and Family Surveys, we examine in a multivariate framework women's transition to marriage and cohabitation, focusing on three indicators of women's autonomy: education, employment and independent living. We also examine whether the effect of these factors has changed over time. 


\section{Theoretical background and hypotheses}

Economic and sociological theories of marriage have long emphasized the impact of women's education and employment on union formation. According to the new home economics, women's growing economic independence is the major factor behind the rise in delayed marriages, forgone marriages and unstable marriages (Becker 1981). This theoretical approach emphasizes the concepts of specialization and exchange to posit the negative relationship between women's economic resources and marriage formation. It assumes that the gendered division of labour within the family -men in paid employment and women in unpaid domestic work - is advantageous for women with low education and low returns in the labour market, but less so for women who are well positioned in the labour market. From this perspective, the more human capital a woman accumulates and the higher her earnings' potential, the lower the incentive (and need) to enter marriage.

Although intuitively appealing, the independence hypothesis has always lacked strong empirical support. There is certainly an observable parallelism over time between women's rising educational attainment and labour force participation, on the one hand, and fewer marriages on the other. But coinciding time trends do not imply any causal link. Several studies based on individual-level data have shown that women's higher education leads to a postponement of marriage, but not to a retreat from it (Hoem 1986; Blossfeld and Huinick 1991).

One of the major criticisms of the independence hypothesis is that the model of gender role specialization within the family on which it is built is outdated and no longer sustainable. As Oppenheimer (1994) argues, gendered specialization is a risky strategy for a nuclear family in today's world. Contrary to Becker's presumption that education increases the benefits of marriage for men but reduces these gains for women, Oppenheimer claims that education has analogous effects among men and women: high educational attainment would foster marriage for both. Women's current or potential earnings would not only facilitate marriage, but in many cases would make it feasible. Given the current labour market context, with high rates of unemployment, underemployment and unstable jobs, the "dual earner strategy" has become the most rational option for young couples, and can also be seen as an insurance against future risks of income loss.

The inconsistent effects that have been found for women's education on union formation in different countries have drawn attention to the crucial role of a society's prevailing gender role differentiation (Ono 2003). In a social setting where individuals and organizations operate assuming a gendered division of work within the family, educated women might be discouraged from entering marriage, since they would have to confront both a second shift and restricted job careers. Conversely, in a more 
egalitarian context, both men and women would be positively evaluated by potential partners if they are able to contribute economically to the household (Sweeney and Cancian 2004). According to this perspective, the effect of women's education and earnings potential would be contingent on a society's gender regime.

Most studies examining the independence hypothesis have focused on marriage, but the emergence of cohabitation has altered the logic underlying union formation decisions. The traditional assumption is that improvements in women's economic position reduce the gains of gender-specialized marriage, but what if gender relations change within the partnership? Would education encourage then union formation? Several studies have shown that more egalitarian attitudes are positively associated with the decision to cohabit (Clarkberg et al. 1995; Kaufman 2000, Moors 2000), and that cohabiting couples have a more symmetrical division of labour (Batalova and Cohen 2002; Baxter 2005). Theoretical perspectives which place emphasis on ideational factors, instead of economic factors, also claim that women's education and autonomy lead to broader life course options and a preference for cohabitation over marriage (Lesthaeghe and Meekers 1986). Cherlin (2000) argues that unmarried cohabitation can offer a good testing ground for men's willingness to share domestic responsibilities. Since women with high earnings potential can achieve economic stability on their own, they might be more selective of partners who would do their fair share of housework and childcare, and might use cohabitation as a trial stage in the process of family formation. Education, hence, does not necessarily affect the formation of consensual unions in the same way it affects marriage.

In this paper we examine the effects of education on marriage and cohabitation in two Southern European countries where gender equality has improved at different speeds in the public and private domains. Both in Spain and Portugal, women's educational attainment and labour force participation among young cohorts are very similar to their male counterparts, although their rates of unemployment, temporary employment and underemployment remain higher than men's. In spite of women's remarkable progress in the public domain, both societies are still organized on the basis of a traditional model of gendered responsibilities within the family (Trifiletti 1999). The unpaid work of women as carers within the family remains an important pillar for social welfare, and public policies aimed at balancing family and work responsibilities remain underdeveloped (Pfau-Effinger 2003).

Our hypothesis is that given the divergent levels of gender equity that prevail in the public and private domains, high educational attainment will discourage marriage but encourage cohabitation, since the latter entails less pressure to conform to traditional gender roles. Although the effects of women's education and employment on union formation have been commonly assumed to follow a similar pattern, the erosion of the male breadwinner family model in both societies and the increasing uncertainty 
in the labour market has made employment a prerequisite for household formation for both partners. Therefore, we do not expect to find a negative effect of women's employment on first partnership formation, whether marriage or cohabitation. Nevertheless, given the large contrasts in women's education, employment patterns and attitudes in coexisting cohorts, we anticipate the effect of women's education and employment on union formation to have changed over time.

In addition to education and employment, we focus on a third indicator of women's autonomy: living away from the family of origin. One distinctive feature of Southern European countries is the late departure from the parental home and its close association with partnership formation (Fernández Cordón 1997; Billari et al. 2001; Aassve et al. 2002; Holdsworth 2005). The increasing age at leaving home observed among recent cohorts (Billari et al. 2002) appears to run counter to most major social trends associated with the second demographic transition, which reflect individuals' search for privacy, autonomy, self-realization and a less structured life course (van de Kaa 1987). Economic barriers to independent living, such as high youth unemployment, decreasing job security and escalating housing costs, seem to underlie the observed patterns of departure from the parental home. The tendency of prolonging the period during which young adults remain dependent or semi-dependent upon their parents, which seems to be at odds with the dramatic increase in women's educational attainment and attachment to the labour force, leads us to distinguish between potential and actual economic independence. Whereas some decades ago, the economic independence of a woman with a college degree and a job would be out of the question, nowadays, high educational credentials and employment do not guarantee economic independence in Southern European countries, due to the high prevalence of temporary work contracts and low salaries even among highly-qualified young adults (Golsch 2003). By contrast, residential emancipation typically requires economic selfsufficiency and implies wide social autonomy. For this reason, in addition to the indicators usually employed in testing the independence hypothesis, educational level and employment, we will also look at the experience of non-family living.

Living away from the parental home during early adulthood, aside from being a fairly robust indicator of economic independence, has also been shown to shape women's attitudes, reducing their orientation to traditional family roles and, consequently, influencing their life course plans (Goldscheider and Waite 1987). The experience of a family "role hiatus", that is, time outside the traditional family roles of daughter, wife or mother, introduces alternative life-style options in which adult roles are not constrained by traditional gender roles, and provides women with a sense of independence and self-confidence, as well as a propitious context to develop tastes for non-familial roles (Presser 1971; Mason 1974). Accordingly, we hypothesize that women who have experienced non-family living in their transition to adulthood are 
more likely to delay union formation and to choose cohabitation over marriage as their first conjugal union, particularly in societies characterized by relatively inegalitarian gender relations within marriage.

\section{Women's changing social and economic position in Spain and Portugal}

Spain and Portugal share similar recent trajectories in the economic, political and social fronts: they exited a dictatorial regime in the mid-1970s and both entered the EU in 1986, they have weak welfare states and their social organization is characterized by relatively strong family-ties and low investment in public policies for families. Although the Catholic Church has lost its traditional power of shaping family-related legislation - as reflected in the bill passed in 2005 by the Spanish Parliament that enables same-sex marriages or the liberalization of Portugal's abortion laws in 2007, it retains significant influence on social habits. There are, however, some important differences. For instance, women's advancement in education has been more rapid in the case of Spain, whereas women's integration in the labour force has been more rapid in the case of Portugal. Consequently, we expect to find many similarities, but also some divergences, in women's partnership formation patterns in these two societies.

Women's educational advancement in Southern Europe since the second half of the twentieth century has been remarkable (González 2000). Both Spain and Portugal have reduced the large educational gap that had traditionally existed with respect to the rest of Europe, particularly after the advent of democracy. For younger generations, access to university is no longer restricted to the upper social classes and women have even surpassed men in tertiary education enrolment since the 1990s in both countries.

Figure 1 shows the proportion of college educated women and men for successive age groups according to the 2001 census. Both women and men have improved their educational attainment, but the advancement of women has been more impressive. Whereas less than $5 \%$ of Spanish women born in the late 1930s had access to university education, nearly one third of women born in the early 1970s have attended college, surpassing their male counterparts by 10 percentage points. Portuguese women have also experienced remarkable educational gains. The proportion of women born in the early 1970s who have attended college (22.7\%) almost doubles that of men, although it is below that of their Spanish counterparts. 
Figure 1: Percentage of women and men with college education by age group. Spain and Portugal, 2001
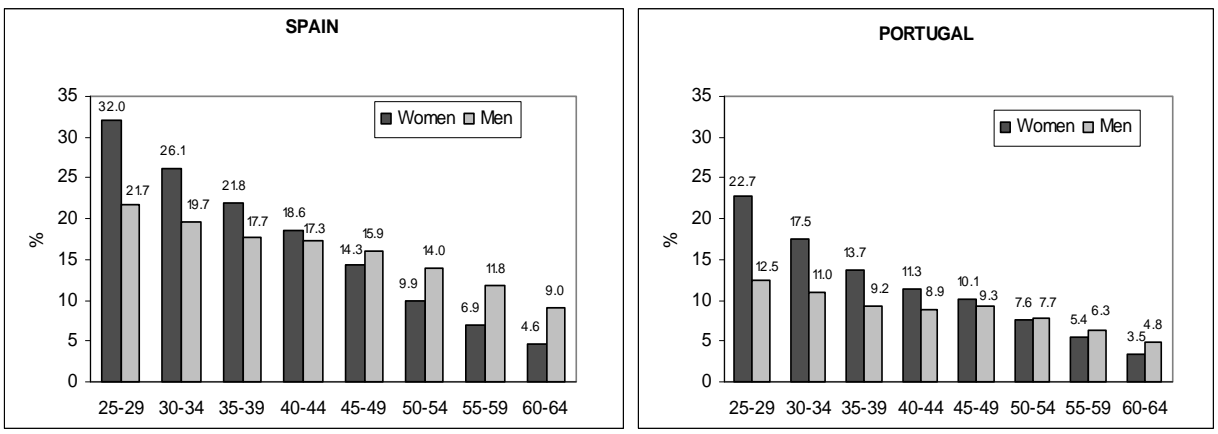

Sources: 2001 Census Spain; 2001 Census Portugal.

With the improvement of female education and corresponding earnings potential, women's working aspirations and actual attachment to the labour force have changed dramatically. Since the mid-1970s, women's labour force participation increased rapidly in Portugal and has been above the EU average for the past two decades. The evolution in Spain has been slower and the overall female labour force participation rate in 2006 (48\%) remained well below the EU-25 average (63\%). However, as illustrated in Figure 2, younger cohorts display a similar rate of labour force participation to their European counterparts: 78.5\% of Spanish women aged 30-34 were economically active in 2006, a proportion which is very close to the EU-25 average for this age group (77.4\%), although lower than in Portugal (88\%).

Despite considerable progress, it should be noted that, in the case of Spain, women's incorporation into the labour market has not been a smooth process (Simó et al. 2005). The unemployment rate averaged $20 \%$ in the 1980 s and the first half of the 1990s, a rate more than double the EU average and far exceeding that of any other industrial society. This high level of unemployment was not evenly distributed, but largely concentrated among young adults and women. Unemployment has declined considerably in recent years, but the gender gap persists: in 2006, $11.6 \%$ of women compared to $6.3 \%$ of men were unemployed, and the corresponding rates among women and men aged $20-24$ were $17.8 \%$ and $12.3 \%$. Unemployment rates have been consistently lower and the gender gap narrower in Portugal (Bermeo 2001). In 2006, $8.7 \%$ of Portuguese women compared to $6.8 \%$ of men were unemployed. 
Figure 2: $\quad$ Labor force participation rate for women and men aged 30-34. Spain, Portugal, and EU-25, 2006

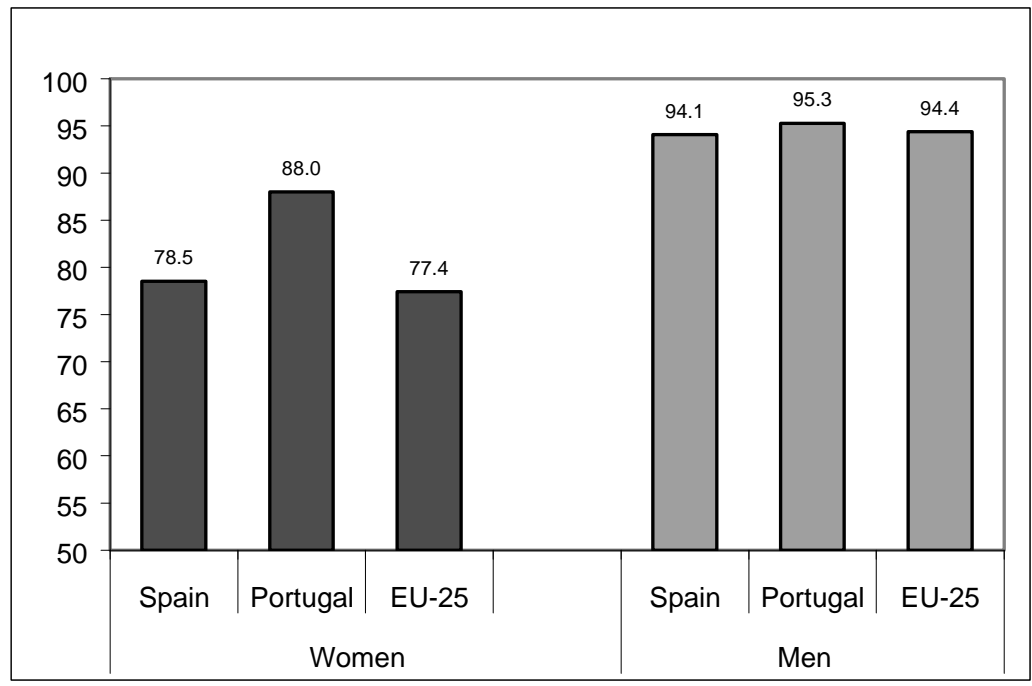

Source: EUROSTAT, Population and Social Conditions.

With regard to recent trends in independent living, a previous study based on FFS data (Billari et al. 2002) revealed that, contrary to the evolution observed in Northern Europe, Southern European countries display a downward trend in the propensity to leave the parental home in order to live independently in a non-family household. Although we would expect young women's expanding education and labour force participation to encourage residential emancipation, it seems that economic constraints, derived from job instability, low salaries and high housing costs, restrain potential aspirations of autonomy (Tobío 2001; Golsch 2003).

The transformation in the social status and economic behaviour of women has occurred in parallel with broad ideational changes. In many comparative studies, Spain and Portugal are usually classified as "traditional" societies in terms of values, due in part to their Catholic inheritance. And this was certainly so in the past, but recent public opinion surveys reveal that gender equalitarian values and tolerance towards new family forms are now widespread in both societies (Almeida and Wall 2001). Table 1 shows the percentage of women aged 18-49 that agreed to several items related to gender equality and new family behaviour, according to the Spanish and Portuguese ISSP Survey on Family and Gender Roles 2002. The corresponding percentages for 
college educated women are also shown. In general, responses do not conform to a pattern of traditional family values. Only a minority of women agree with the statement "A man's job is to earn money; a woman's job is to look after the home and the family", although the level of agreement is higher among Portuguese women (17.7\%) than Spanish women (10\%), despite the higher labour force participation rate of the former. Support for gender role specialization declines even further among college educated women.

Table 1: Attitudes towards gender roles and new family forms

\begin{tabular}{|c|c|c|c|c|}
\hline \multirow[t]{2}{*}{$\%$ that agrees/strongly agrees with the statement: } & \multicolumn{2}{|c|}{ All women 18-49 } & \multicolumn{2}{|c|}{$\begin{array}{l}\text { College-educated } \\
\text { women }\end{array}$} \\
\hline & Spain & Portugal & Spain & Portugal \\
\hline $\begin{array}{l}\text { "A man's job is to earn money, a woman's job } \\
\text { is to look after the home and children" }\end{array}$ & 10.0 & 17.7 & 2.9 & 3.5 \\
\hline $\begin{array}{l}\text { "It is a good idea for a couple who intend to } \\
\text { get married to live together first" }\end{array}$ & 80.5 & 59.7 & 76.8 & 66.7 \\
\hline $\begin{array}{l}\text { "It is all right for a couple to live together without } \\
\text { intending to get married" }\end{array}$ & 87.6 & 89.7 & 91.3 & 93.0 \\
\hline "People who want children ought to get married" & 17.6 & 26.6 & 10.1 & 15.8 \\
\hline
\end{tabular}

Regarding new family forms, although the diffusion of cohabitation is still low in both countries, social attitudes reflect an open mind towards this type of partnership. Nearly 9 out of 10 women interviewed both in Spain and Portugal agreed with the statement "it is all right for a couple to live together without intending to get married", although support for cohabitation as a probation period in the pathway to marriage was lower in Portugal than in Spain. Social approval of childbearing outside marriage is also widespread: only $17.6 \%$ of Spanish women and $26.6 \%$ of Portuguese women agreed with the statement "people who want children ought to get married". As expected, college educated women show a higher acceptance of new family forms than average. Tolerance towards alternative families is likely to be shaped by religious beliefs. Catholic precepts explicitly forbid premarital sex and non-marital unions, but these precepts have been losing significance due to the rapid secularization process. According to the same survey, only $13 \%$ of Spanish women and $27.6 \%$ of Portuguese women below age 50 report regular church attendance. 
Although the traditional male breadwinner/female homemaker family model has been substantially eroded (Luxán et al. 1998), and most women (and men) endorse the dual-earner family model, progress in the reallocation of unpaid housework and care responsibilities within the family has been slow. Women's earnings potential is expected to increase their bargaining power at home. However, whereas Spanish and Portuguese women's educational resources and labour market behaviour have rapidly approached those of men, the private domain remains strongly gender-specialized. The ISSP Survey on Family and Gender Roles 2002 contains several questions on who typically performs a variety of household tasks. Figure 3 shows a comparison based on couples where both partners work. The data reflect a highly asymmetrical division of domestic labour. Despite the fact that all women under study are economically active, they continue to do the majority of housework, both in Spain and Portugal.

Figure 3: Percentage of double earner couples in which women alone are responsible for housework

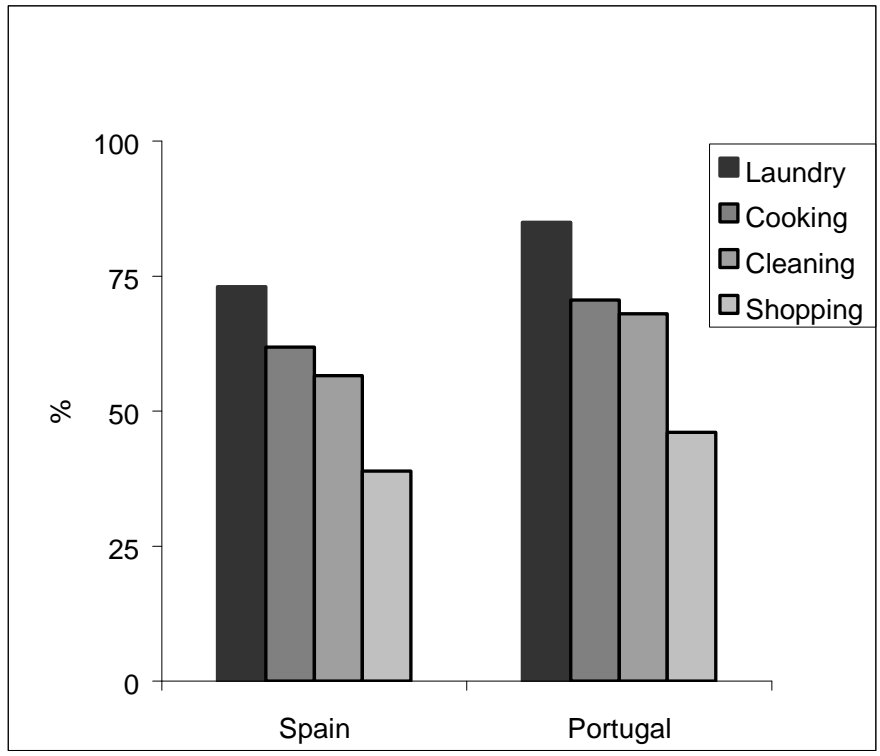

Source: ISSP, 2002.

In sum, we have seen that women in both countries have experienced substantial progress in terms of education and paid work. In fact, current educational and labour force participation indices for young Spanish and Portuguese women are not behind 
their counterparts in the rest of Europe. Social norms and values regarding gender roles and new family forms have also undergone an impressive change. However, the division of unpaid labour at home continues to be highly asymmetrical. It is in this context of inconsistent levels of gender equity in the public and private domains that we expect female education to discourage marriage, but less so cohabitation as a trial period. Before testing the effect of education, we will briefly review nuptiality trends in both countries.

\section{Recent nuptiality trends}

As illustrated in Figure 4, Spain and Portugal have undergone a trend towards marriage postponement similar to that observed in the rest of European countries. In 2004, Spanish women's mean age at first marriage (29.2) was above the EU-25 average (28.0), although that of Portuguese women remained below it (26.4). This apparent convergence in the timing of family formation is, however, somewhat deceptive. Whereas in most European countries first marriage is usually preceded by cohabitation and, consequently, partnership formation occurs significantly earlier than reflected in marriage statistics (Kiernan 2000b), in Southern Europe the prevalence of cohabitation is still relatively low and, hence, the documented late pattern of entry into marriage implies also a late pattern of entry into first partnership (Castro-Martín et al. 2008). According to 2001 Census data, $70.1 \%$ of Spanish women and 53.3\% of Portuguese women in their 20s had never entered a conjugal union.

Despite low diffusion, cohabitation is abandoning its traditionally marginal position. Cross-sectional data from the 2001 census, shown in Figure 5, reveal that $33.5 \%$ of all conjugal unions among women aged $20-24$ and $16.6 \%$ among women aged 25-29 were non-marital unions in Spain. And the corresponding figures for Portugal were $20.1 \%$ and $12.5 \%$. Since cohabitation in Southern Europe tends to be a transitory stage in couples' life-course (Heuveline and Timberlake 2004) and its duration is typically short - because of separation or transition to marriage ${ }^{3}$, the prevalence captured in cross-sectional data provides only an underestimate of the proportion of women who have ever experienced this type of union. Nevertheless, these data indicate that cohabitation can no longer be overlooked when examining union formation patterns.

${ }^{3}$ According to FFS data, 15\% of Spanish cohabiting couples had separated and 34\% had transformed their union into marriage after 3 years. 
Figure 4: Trends in female mean age at first marriage. Spain, Portugal and EU-25, 1975-2004

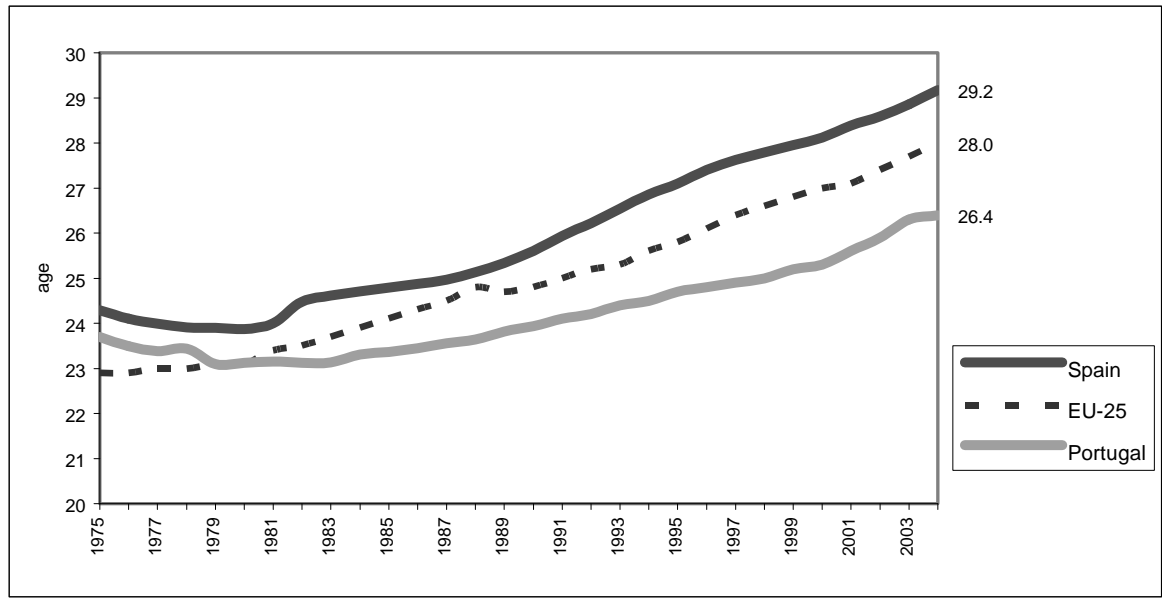

Source: EUROSTAT.

Figure 5: Proportion of cohabiting women among all women in union, by age group. Spain and Portugal, 2001

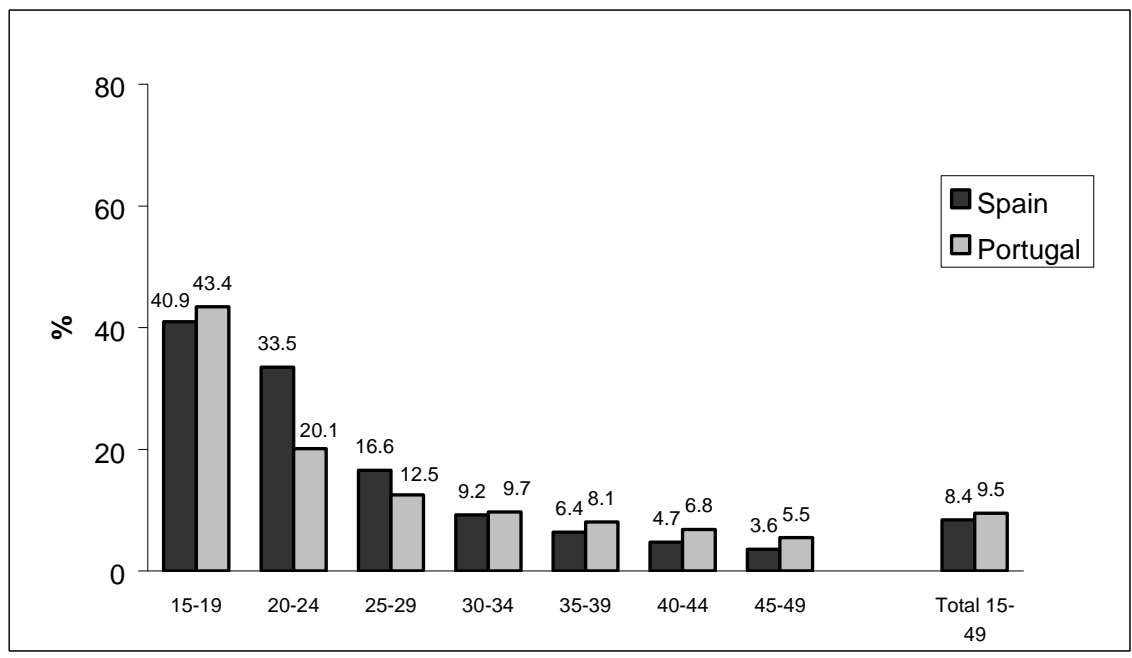


Source: 2001 Census Spain, 2001 Census Portugal

The comparison of census data also reveals important differences related to childbearing among cohabiting couples in Spain and Portugal. As shown in Figure 6, the proportion of cohabiting women with children was significantly higher in Portugal (68.8\%) than in Spain (48.3\%). If we restrict the comparison to younger women, whose children are less likely to belong to prior unions, differences are even larger: the proportion of cohabiting women aged $25-29$ with children was $60.1 \%$ in Portugal compared to $28.4 \%$ in Spain. These data suggest that, although cohabitation is an emerging trend in both countries, its role within the family formation system might be different.

Figure 6: Proportion of cohabiting women living with children by age group. Spain and Portugal, 2001

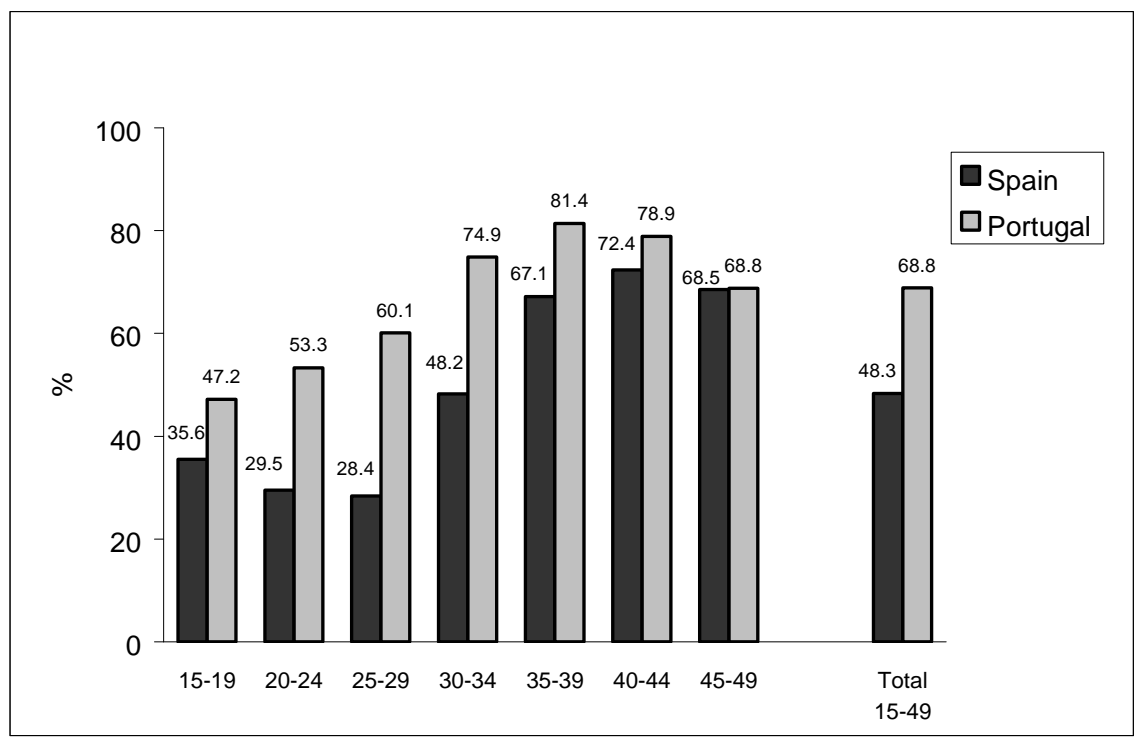

Source: 2001 Census Spain, 2001 Census Portugal

\section{Data and methods}

In the former descriptive section, we have used data from the Spanish and Portuguese censuses conducted in 2001, as well as the ISSP Family and Gender Roles Survey 
conducted in 2002. For the multivariate analysis, we use data from the Fertility and Family Surveys (FFS). The primary disadvantage of the FFS is that, in the case of Spain and Portugal, it is more than 10 years old, and it is precisely in the past decade where changes in family behaviour have accelerated - as reflected in the increase in nonmarital fertility from $11.1 \%$ to $28.4 \%$ in Spain and from $18.7 \%$ to $31.6 \%$ in Portugal in the period 1995-2006. However, the FFS remains the best source for comparing union formation patterns in these two countries and, since it encompasses a period of significant educational advancement for women, it can provide important clues on the influence of education on women's union choices. The Spanish FFS, conducted in 1995, interviewed 4,021 women aged 18 to 49, and collected retrospective information on partnership, childbearing, educational and work biographies. The Portuguese FFS was conducted in 1997 and interviewed 5,954 women. However, the Portuguese questionnaire was shorter than the standard one and it did not collect retrospective employment histories and other variables relevant for the study of union formation, such as religiosity or size of city of residence. Consequently, the analyses run for both countries are similar but not identical.

We focus on three indicators of women's autonomy: educational attainment, employment status and living independently without a partner. Education is the most commonly used proxy for human capital and earnings potential. We distinguish between primary school, lower secondary, upper secondary (beyond the compulsory level) and university, and we also include a time-varying covariate indicating enrolment status in order to separate the effects of school enrolment and schooling accumulation. Employment status is measured on a monthly basis as a time-varying covariate in the case of Spain, but for Portugal, given the lack of work biographies, we can only use a crude indicator differentiating women who have ever worked from those who have never worked. To measure independent living, we identify those respondents who left the parental home to live alone or with unrelated adults - before union or interview for at least one year. In addition, we include in the models a number of background variables which have been identified as influential in the literature on union formation (Kiernan 2000a): size of family of origin, experience of parental divorce and, in the case of Spain, religious practice and urban residence. Information on women's fertility status is also entered in the model as a time-varying covariate. Its value changes from childless to pregnant eight months before the reported date of birth and then changes to birth. Due to common underreporting of terminated pregnancies, we only identify conceptions that resulted in a live birth.

Discrete-time multinomial logistic regression is used to estimate simultaneously the odds of marrying, cohabiting or remaining single. The observation starts at age 14 and, since the analysis is based on person-months of exposure to the competing risks of marriage or cohabitation, our approach is similar to a continuous-time hazard model 
(Allison 1984). Odds ratios for several contrasts are shown: entering any union, marriage and cohabitation versus remaining single, as well as entering cohabitation versus marriage.

We examine changes over time in the patterns of union formation comparing the biographies of three cohorts: women born in 1945/7-1954, 1955-1964 and 1965-1977/9. The educational and cultural context while growing up and the socioeconomic setting in which these cohorts reached adulthood differs significantly, presumably shaping different dynamics of union formation. The 1945/7-1954 cohort was born in a period of economic deprivation, low educational opportunities and rigid moral codes, but entered adulthood in a period of economic expansion and optimism on the prospects of upward social mobility. The 1955-1964 cohort enjoyed the benefits of an expanding educational system and an incipient welfare state, and witnessed the process of democratization during their adolescence, but entered the labour market in a period of rising unemployment. The 1965-1977/9 cohort was largely socialized in a context of democratic values and gender equality norms, and enjoyed broad access to secondary and post-secondary education, but faced a situation of scarce and unstable jobs when reaching adulthood. We examine whether the effect of educational attainment and employment on union formation choices has changed across cohorts, by presenting separate models for each cohort.

\section{Results}

\subsection{Factors influencing women's transition to first union}

Tables 2a and $2 \mathrm{~b}$ present, for Spain and Portugal respectively, the relative risks associated with selected covariates on the rate of transition to first union regardless of union type (Column 1), to first marriage (Column 2) and to first cohabitation (Column 3) relative to remaining single. Because some of the arguments formerly presented concern the effect of women's independence on the choice between cohabitation and marriage, Column 4 shows the contrast of cohabitation relative to marriage. 
Table 2a: Odds Ratios from multinomial logistic regression on entry into marriage and cohabitation, Spain

\begin{tabular}{|c|c|c|c|c|c|c|c|}
\hline & $\begin{array}{c}\text { Any union } \\
\text { vs. } \\
\text { no union }\end{array}$ & & $\begin{array}{c}\text { Marry } \\
\text { vs. } \\
\text { no union }\end{array}$ & $\begin{array}{c}\text { Cohabit } \\
\text { vs. } \\
\text { no union }\end{array}$ & & $\begin{array}{c}\text { Cohabit } \\
\text { vs. } \\
\text { Marry }\end{array}$ & \\
\hline \multicolumn{8}{|l|}{ Birth cohort } \\
\hline$(1945-1954)$ & 1.00 & & 1.00 & 1.00 & & 1.00 & \\
\hline $1955-1964$ & 1.20 & 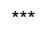 & $1.18^{\star \star \star}$ & 1.76 & 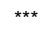 & 1.48 & * \\
\hline 1965-1977 & 0.76 & $* \star \star$ & $0.64^{\star \star *}$ & 2.66 & $* \star \star$ & 4.12 & *** \\
\hline \multicolumn{8}{|l|}{ Educational attainment } \\
\hline (Primary) & 1.00 & & 1.00 & 1.00 & & 1.00 & \\
\hline Lower Secondary & 0.90 & 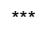 & $0.89 \star \star \star$ & 1.25 & & 1.39 & * \\
\hline Upper Secondary & 0.66 & 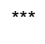 & $0.63 * \star \star$ & 1.16 & & 1.83 & ** \\
\hline University & 0.74 & $* \star \star$ & $0.69 * \star *$ & 1.41 & & 2.04 & $* \star \star$ \\
\hline Enrolled in education $^{t}$ & 0.52 & $* \star \star$ & $0.44^{* * *}$ & 0.89 & & 2.03 & $* * *$ \\
\hline Employed $^{t}$ & 1.17 & $\star \star \star$ & $1.11 * \star$ & 1.80 & $* * *$ & 1.61 & $* \star *$ \\
\hline Has lived independently & 0.95 & & $0.69 \star \star \star *$ & 3.73 & 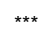 & 5.38 & $* * *$ \\
\hline \multicolumn{8}{|l|}{ Fertility status ${ }^{t}$} \\
\hline (Childless) & 1.00 & & 1.00 & 1.00 & & 1.00 & \\
\hline Pregnancy & 1.70 & $* \star \star$ & $1.81 * \star *$ & 0.84 & & 0.46 & $* * *$ \\
\hline Birth & 0.54 & *** & 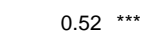 & 0.87 & & 1.67 & \\
\hline Siblings 3+ & 1.10 & $\star \star \star ~$ & $1.08^{* * *}$ & 1.39 & $\star \star \star *$ & 1.28 & ** \\
\hline Parental separation & 1.18 & 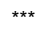 & 0.95 & 2.36 & $* \star \star$ & 2.48 & *** \\
\hline Size town $100,000+$ & 1.01 & & 0.96 & 1.39 & $* \star \star$ & 1.44 & $* * *$ \\
\hline \multicolumn{8}{|l|}{ Religious practice } \\
\hline (Once a week) & 1.00 & & 1.00 & 1.00 & & 1.00 & \\
\hline Sometimes & 1.06 & & 1.02 & 2.91 & 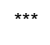 & 2.85 & $* * *$ \\
\hline Never & 1.10 & $\star \star \star$ & 0.98 & 5.74 & 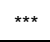 & 5.85 & $* \star *$ \\
\hline
\end{tabular}

${ }^{\star} p<.05,{ }^{\star *} p<.01,{ }^{\star \star *} p<.001$

Notes: Reference categories in parentheses; ${ }^{\mathrm{t}}$ time-varying covariate. 
Table 2b: Odds Ratios from multinomial logistic regression on entry into marriage and cohabitation, Portugal

\begin{tabular}{|c|c|c|c|c|c|c|c|c|}
\hline & $\begin{array}{l}\text { Any union } \\
\text { vs. } \\
\text { no union }\end{array}$ & & $\begin{array}{c}\text { Marry } \\
\text { vs. } \\
\text { no union }\end{array}$ & & $\begin{array}{l}\text { Cohabit } \\
\text { vs. } \\
\text { no union }\end{array}$ & & $\begin{array}{c}\text { Cohabit } \\
\text { vs. } \\
\text { Marry }\end{array}$ & \\
\hline \multicolumn{9}{|l|}{ Birth cohort } \\
\hline$(1947-1954)$ & 1.00 & & 1.00 & & 1.00 & & 1.00 & \\
\hline $1955-1964$ & 1.12 & ** & 1.05 & & 1.53 & $\star \star \star$ & 1.45 & $\star \star$ \\
\hline 1965-1979 & 0.91 & * & 0.74 & $\star * *$ & 1.95 & $\star \star \star *$ & 2.62 & $\star \star \star *$ \\
\hline \multicolumn{9}{|l|}{ Educational attainment } \\
\hline (Primary) & 1.00 & & 1.00 & & 1.00 & & 1.00 & \\
\hline Lower Secundary & 0.48 & $\star \star \star$ & 0.44 & $\star * *$ & 0.61 & $* * *$ & 1.37 & \\
\hline Upper Secondary & 0.24 & $\star \star \star$ & 0.25 & $\star \star \star *$ & 0.23 & $\star * \star$ & 0.94 & \\
\hline University & 0.39 & 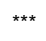 & 0.41 & $\star * \star$ & 0.36 & $* * *$ & 0.88 & \\
\hline Ever worked & 1.46 & $\star \star \star *$ & 1.38 & $\star \star \star *$ & 1.86 & $\star * \star$ & 1.34 & * \\
\hline Has lived independently & 1.01 & & 0.80 & $\star \star \star *$ & 1.94 & 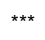 & 2.42 & 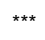 \\
\hline \multicolumn{9}{|l|}{ Fertility status $^{t}$} \\
\hline (Childless) & 1.00 & & 1.00 & & 1.00 & & 1.00 & \\
\hline Pregnancy & 1.60 & $\star \star \star *$ & 1.70 & $\star * \star$ & 1.18 & & 0.69 & $\star \star$ \\
\hline Birth & 0.48 & 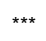 & 0.33 & $\star \star \star \star$ & 1.17 & & 3.48 & $\star \star \star$ \\
\hline Siblings 3+ & 1.09 & ** & 1.04 & & 1.28 & * & 1.22 & \\
\hline Parental separation & 1.14 & ** & 0.88 & & 1.88 & 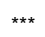 & 2.12 & $\star \star \star *$ \\
\hline
\end{tabular}

${ }^{\star} \mathrm{p}<.05,{ }^{* \star} \mathrm{p}<.01,{ }^{* \star \star} \mathrm{p}<.001$

Notes: Reference categories in parentheses; ${ }^{t}$ time-varying covariate.

Birth cohort differentials are sizeable for all the contrasts presented. Consistent with the general pattern of the second demographic transition, the youngest cohort displays a significantly lower likelihood of entering marriage but a higher likelihood of entering cohabitation than the oldest cohort both in Spain and Portugal. However, the increase in cohabitation is not large enough to counteract the decline in marriage, and the overall rate of partnership formation, regardless of union type, is lowest for the youngest cohort, particularly in Spain. 
Turning to the indicators of women's independence, we can observe that, although the effect of schooling accumulation is not linear, women's educational attainment has a negative effect on the likelihood of entering marriage both in Spain and Portugal, as predicted by the independence hypothesis. The odds of entering marriage among college educated women are $31 \%$ lower than among women with primary schooling in Spain and 59\% lower in Portugal. However, the influence of female education on cohabitation is not equivalent in both countries. In Spain, college education does not significantly increase the odds of entering cohabitation relative to remaining single, but increases substantially the likelihood of entering cohabitation versus marriage (an odds ratio of 2.04). By contrast, in Portugal, college educated women are significantly less likely to enter cohabitation than women with primary education. Retrospective data on school enrolment were only available for Spain, but results are consistent with previous studies (Coppola 2004): students are considerably less likely to enter marriage than non-students, probably because they are often economically dependent upon their parents and there are strong norms of incompatibility between student and spouse roles. The effect of school enrolment on the transition to cohabitation, however, is not statistically significant.

The effect of employment status is more in line with Oppenheimer's argument that women's earnings facilitate union formation than with Becker's assumption that women's economic self-sufficiency reduces the gains of marriage, but also provides some evidence of the preference for cohabitation over marriage among economically independent women. In Spain, the odds of entering marriage relative to remaining single are $11 \%$ higher among employed than unemployed women, but at the same time, the odds of entering cohabitation relative to entering marriage are $61 \%$ higher among employed than unemployed women. In Portugal, the data available did not allow the construction of a time-varying covariate of employment status, but the crude indicator used follows the same pattern: having ever worked is positively associated with marriage but more so with cohabitation.

The third indicator of women's independence, having lived away from the parental home for at least one year, reduces the likelihood of entering marriage in both countries, but is positively associated with entry into cohabitation. Residential - and presumably economic - emancipation from the parental family increases the chances of cohabiting by a factor of 3.7 in the case of Spain and a factor of 1.9 in the case of Portugal. ${ }^{4}$

\footnotetext{
${ }^{4}$ Although our focus is on women's partnership behaviour, we have also conducted a parallel analysis for males, in order to explore gender differentials in the influence of educational attainment, employment and living independently from the family of origin on union formation. The results (which are shown in Table A1 in the Appendix) should be interpreted with caution because of the restricted sample size for men, but they reveal certain divergences. In contrast to the effect of women's education, men's higher educational attainment increases the rate of transition to marriage in Spain and has no significant effect in Portugal. Men's employment increases the likelihood of transition to both marriage and cohabitation in Spain, although, in
} 
The effects of the rest of the background variables are consistent with those documented in the literature. Pregnancy accelerates the transition to marriage, whereas the presence of non-marital children reduces considerably the odds of marriage. The effect of pregnancy and non-marital childbearing on the transition to cohabitation relative to remaining single is not statistically significant, but if we compare the odds of entry into cohabitation relative to marriage, the results suggest that pregnant women are more likely to enter marriage than cohabitation, and the opposite pattern is observed for single mothers. Parental separation also influences the type of first union women enter. The relative risks of cohabitation versus marriage are approximately double among women who experienced their parents' separation than among women that were raised in a two-parent family. Growing up in a large family increases the likelihood of entering a union both in Spain and Portugal, but has a stronger effect on cohabitation than on marriage. Information on the size of the place of residence and religious practice was only available for the Spanish data, and the results are in the expected direction: living in a large city and having low religious practice do not have a significant influence on the likelihood of marriage, but increase considerably the chances of entering cohabitation. Spanish women who never attend church are nearly 6 times more likely to cohabit than women with regular church attendance.

\subsection{The changing effect of women's education and employment across cohorts}

In the previous section, we have seen that the effect of women's education on marriage is consistent with the independence hypothesis, but that the effect of employment is not. These overall effects may reflect changing underlying relationships over time. Since women's advancement in the social and economic fronts has been particularly rapid in recent decades, large intergenerational contrasts can be found in both countries. Consequently, the effect of women's education and employment on union formation might not be homogeneous across cohorts that were socialized under different gender role norms and that enjoyed different educational and labour market opportunities. Table 3 shows separate models of transition to first partnership for each of the cohorts under study. ${ }^{5}$ Although we only focus on the changing effect of education, employment and independent living, the rest of the covariates are also controlled for in these models.

contrast to women, the odds of marriage are higher than the odds of cohabitation. Lastly, the effect of men's independent living is similar to women's: it discourages marriage and encourages cohabitation both in Spain and Portugal.

${ }^{5}$ Table A2 in the Appendix also shows a pooled model that allows us to test the significance of the interactions between birth cohort and women's education, employment and independent living. 
Table 3: Odds Ratios from multinomial logistic regression on entry into marriage and cohabitation, for successive birth cohorts, Spain and Portugal

\begin{tabular}{|c|c|c|c|c|c|}
\hline & \multicolumn{5}{|c|}{ Cohort 1945/47-1954 } \\
\hline & $\begin{array}{l}\text { Any union } \\
\text { vs. } \\
\text { no union }\end{array}$ & $\begin{array}{c}\text { Marry } \\
\text { vs. } \\
\text { no union }\end{array}$ & $\begin{array}{l}\text { Cohabit } \\
\text { vs. } \\
\text { no union }\end{array}$ & \multicolumn{2}{|c|}{$\begin{array}{c}\text { Cohabit } \\
\text { vs. } \\
\text { Marry }\end{array}$} \\
\hline SPAIN & & & & & \\
\hline \multicolumn{6}{|l|}{ Educational attainment } \\
\hline (Primary) & 1.00 & 1.00 & 1.00 & 1.00 & \\
\hline Lower Secundary & 0.92 & 0.90 & 1.84 & 2.03 & \\
\hline Upper Secondary & $0.74 * \star$ & $0.70 *$ & $2.75 *$ & $3.89 *$ & $\star \star$ \\
\hline University & 0.86 & 0.78 ** & $3.50 * \star$ & $4.44 *$ & $\star \star$ \\
\hline Employed $^{t}$ & $0.67 * \star \star$ & 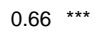 & 1.12 & 1.70 & \\
\hline Has lived independently & 0.90 & $0.83 * *$ & $2.71 \star \star \star \star$ & $3.25 *$ & 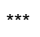 \\
\hline \multicolumn{6}{|l|}{ PORTUGAL } \\
\hline \multicolumn{6}{|l|}{ Educational attainment } \\
\hline (Primary) & 1.00 & 1.00 & 1.00 & 1.00 & \\
\hline Lower Secundary & $0.56 * \star \star$ & $0.49 \star \star \star$ & 0.99 & 2.00 & \\
\hline Upper Secondary & 1.19 & 1.33 & $\ldots$ & $\ldots$ & \\
\hline University & 0.64 & 0.65 & 0.56 & 0.85 & \\
\hline Ever worked & 1.19 ** & 1.16 * & 1.41 & 1.21 & \\
\hline Has lived independently & 0.94 & 0.88 & 1.18 & 1.33 & \\
\hline
\end{tabular}


Table 3: (continued)

\begin{tabular}{|c|c|c|c|c|c|}
\hline & \multicolumn{5}{|c|}{ Cohort 1955-1964 } \\
\hline & $\begin{array}{c}\text { Any union } \\
\text { vs. } \\
\text { no union }\end{array}$ & $\begin{array}{c}\text { Marry } \\
\text { vs. } \\
\text { no union }\end{array}$ & $\begin{array}{l}\text { Cohabit } \\
\text { vs. } \\
\text { no union }\end{array}$ & \multicolumn{2}{|c|}{$\begin{array}{c}\text { Cohabit } \\
\text { vs. } \\
\text { Marry }\end{array}$} \\
\hline SPAIN & & & & & \\
\hline \multicolumn{6}{|l|}{ Educational attainment } \\
\hline (Primary) & 1.00 & 1.00 & 1.00 & 1.00 & \\
\hline Lower Secundary & $0.88^{\star \star \star}$ & $0.88^{\star \star \star *}$ & 0.91 & 1.03 & \\
\hline Upper Secondary & $0.77^{\star \star \star *}$ & $0.74^{\star * \star *}$ & 1.32 & 1.78 & \\
\hline University & $0.85 * *$ & $0.81 \star \star \star *$ & 1.38 & 1.69 & \\
\hline Employed $^{t}$ & $1.21 * * \star$ & $1.21 * \star \star$ & 1.28 & 1.06 & \\
\hline Has lived independently & $0.80^{\star \star \star}$ & $0.60^{\star \star \star \star}$ & $3.05 * \star \star$ & $5.06 *$ & 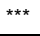 \\
\hline \multicolumn{6}{|l|}{ PORTUGAL } \\
\hline \multicolumn{6}{|l|}{ Educational attainment } \\
\hline (Primary) & 1.00 & 1.00 & 1.00 & 1.00 & \\
\hline Lower Secundary & 0.88 & 0.92 & 0.71 & 0.77 & \\
\hline Upper Secondary & 0.77 & 0.87 & 0.39 & 0.44 & \\
\hline University & 0.73 & $0.45 *$ & 1.42 & 3.11 * & \\
\hline Ever worked & 1.12 & 1.08 & 1.42 & 1.31 & \\
\hline Has lived independently & 1.03 & 0.83 & $2.04 \star \star \star$ & $2.43 *$ & 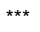 \\
\hline
\end{tabular}


Table 3: (continued)

\begin{tabular}{|c|c|c|c|c|c|}
\hline & \multicolumn{5}{|c|}{ Cohort 1965-1977/79 } \\
\hline & $\begin{array}{l}\text { Any union } \\
\text { vs. } \\
\text { no union }\end{array}$ & \multicolumn{2}{|c|}{$\begin{array}{l}\text { Marry } \\
\text { vs. } \\
\text { no union }\end{array}$} & $\begin{array}{l}\text { Cohabit } \\
\text { vs. } \\
\text { no union }\end{array}$ & $\begin{array}{c}\text { Cohabit } \\
\text { vs. } \\
\text { Marry }\end{array}$ \\
\hline \multicolumn{6}{|l|}{ SPAIN } \\
\hline \multicolumn{6}{|l|}{ Educational attainment } \\
\hline (Primary) & 1.00 & 1.00 & & 1.00 & 1.00 \\
\hline Lower Secundary & $0.79 \star \star \star$ & 0.75 & $\star \star \star ~$ & 1.06 & 1.42 \\
\hline Upper Secondary & $0.53^{\star \star \star}$ & 0.49 & 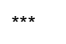 & 0.76 & 4.54 \\
\hline University & $0.50^{\star \star \star}$ & 0.44 & 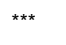 & 0.83 & $1.89 *$ \\
\hline Employed $^{t}$ & $1.86^{\star \star \star}$ & 1.70 & $* \star \star$ & 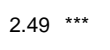 & $1.46 * \star$ \\
\hline Has lived independently & $1.47^{\star \star \star}$ & 0.72 & ** & $4.63 * \star \star$ & $6.35 * \star *$ \\
\hline \multicolumn{6}{|l|}{ PORTUGAL } \\
\hline \multicolumn{6}{|l|}{ Educational attainment } \\
\hline (Primary) & 1.00 & 1.00 & & 1.00 & 1.00 \\
\hline Lower Secundary & $0.37^{\star \star \star}$ & 0.30 & $\star \star \star ~$ & $0.55 * *$ & $1.80 *$ \\
\hline Upper Secondary & $0.18^{\star \star \star}$ & 0.16 & $\star \star \star ~$ & 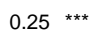 & 1.54 \\
\hline University & $0.29 * \star \star$ & 0.34 & $* \star \star$ & 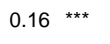 & 0.48 \\
\hline Ever worked & $1.89^{\star \star \star}$ & 1.69 & $\star \star \star$ & $2.48 * \star \star$ & 1.46 \\
\hline Has lived independently & 1.08 & 0.72 & ** & $2.19 \star \star \star$ & $3.01 * \star \star$ \\
\hline
\end{tabular}

${ }^{*} \mathrm{p}<.05,{ }^{* *} \mathrm{p}<.01,{ }^{* \star *} \mathrm{p}<.001$

The models control for school enrollment, fertility status, number of siblings and parental separation.

With regard to the effect of education on marriage, we can observe that it consistently lowers the likelihood of entering marriage in the three cohorts examined and that, both in Spain and Portugal, this negative relationship has become even stronger for the youngest cohort. Regarding the effect of education on cohabitation, we observe that not only the sign but also the pattern of change of this effect differs for Spain and Portugal. In Spain, the effect of education on the likelihood of forming a cohabiting union is positive, but it has weakened over time. In the oldest cohort, the odds of entering cohabitation among college educated women were 3.5 times those of 
women with primary education, possibly because highly educated women acted as forerunners of an unconventional behaviour. In the youngest cohort, which concentrates the majority of cases of cohabitation, college educated women are not significantly more likely to enter cohabitation relative to remaining single, although if they enter a union, they are more likely to opt for cohabitation than marriage. In the Portuguese case, the effect of education on cohabitation is not significant for the older cohorts, but college educated women in the youngest cohort are significantly less likely to enter cohabitation than to remain single.

Although the effect of women's education on union formation has undergone some changes over time, it can be described as relatively stable. In contrast, we can observe a reversal in the effect of women's employment. In Spain, female employment had a negative effect on the rate of entry into marriage and no significant effect on the rate of entry into cohabitation in the oldest cohort. However, the effect of employment becomes positive for entry into marriage in the middle cohort, and positive also for entry into cohabitation in the youngest cohort. Departing from the pattern predicted by the independence hypothesis, the odds of marrying relative to remaining single among employed women born after 1965 are $70 \%$ greater than those of their unemployed counterparts, although concerning union choices, employed women are more likely to opt for cohabitation than marriage. The patterns observed in Portugal are not strictly comparable because we are using a very rough indicator of women's attachment to the labour force. But the effect of women's employment for the youngest Portuguese cohort is similar to that found in Spain: employment is associated with an increased likelihood of entering marriage and cohabitation relative to remaining single, although the contrast between the two union types is not statistically significant.

The third indicator of women's independence we have focused on, having departed from the parental home for at least one year, lowers the odds of marrying and increases the odds of cohabiting both in Spain and Portugal across all cohorts examined. The pattern observed suggests that the effect of independent living encouraging cohabitation over marriage as first union has strengthened over time.

\section{Conclusion}

In this paper we have examined the effect of several indicators of women's autonomy educational attainment, employment and independent living in early adulthood- on first union formation. We wanted to test the independence hypothesis in a context where women's advancement in education and employment has been remarkable but where family relations remain structured along traditional gender roles. Prior studies have shown that it is precisely in societies with inconsistent levels of gender equity in the 
public and private domains where overall fertility is lowest and where evidence for the independence hypothesis is more likely to be found. Although the prevalence of cohabitation remains relatively low in Spain and Portugal, it is an emerging lifestyle that cannot be overlooked when examining partnership dynamics. Accordingly, we have examined whether women's autonomy has different effects on the odds of entering consensual and marital unions.

Our results are mixed depending on the indicator of women's autonomy that we focus on. On the one hand, the effect of education on the rate of entry into marriage is consistent with the independence hypothesis. Better educated women in Spain and Portugal are less likely to enter marriage than their less educated counterparts, and this relationship has strengthened over time. Since education is not only associated with higher expected earnings but also with higher demands of gender equity within partnerships, and cohabitation usually entails more egalitarian gender roles, we expected women's education to be negatively associated with marriage but positively associated with cohabitation. The analysis, however, revealed that education deters cohabitation in Portugal and that, in the case of Spain, education favours cohabitation over marriage, but not cohabitation over remaining single. A recent study by González et al. (2006) has found that, departing from the patterns documented in other countries, consensual unions did not entail significantly more egalitarian relationships and higher male involvement in caring activities in Southern Europe. This might be one of the reasons why cohabitation is not attractive enough to "compete" with remaining single among highly educated women.

Whereas the effect of women's education is consistent with the independence hypothesis among all the cohorts examined, the effect of female employment has reversed over time in Spain. For the oldest cohort, women's paid work was associated with a lower risk of entry into marriage, as predicted by the independence hypothesis, but in the youngest cohort, women's employment is associated with a higher rate of union formation, although it favours cohabitation over marriage.

The fact that the effects of women's education and employment are not in the same direction might reflect the current difficulties involved in attaining actual "independence". For the youngest cohort, which has largely benefited from the remarkable expansion of higher education, college credentials no longer guarantee access to a professional occupation, and paid work no longer guarantees long-term economic self-sufficiency in a context of increasingly precarious work relationships $47 \%$ of employed Spanish women aged 25 to 29 held a temporary contract in 2005 -. Given the erosion of the male breadwinner model, the employment of both partners has become a precondition for marriage, but not all jobs entail actual economic independence for women. A refined test of the independence hypothesis would require further information on women's job stability and actual earnings. 
Emancipation from the parental home for at least one year is probably a more accurate proxy for economic independence than education and employment in the current socioeconomic context, and its effect is consistent both with the independence hypothesis - it lowers the likelihood of entering marriage relative to remaining single and with the gender equity argument - it increases the odds of cohabiting relative to marrying.

In sum, this study has shown that women's increasing social and economic autonomy in Spain and Portugal has had a significant impact on union formation patterns, but also that the rationale underlying nuptiality behaviour is certainly more complex than originally postulated by the classical independence hypothesis. It is evident that educated women have less need for economic insurance via a marriage contract, and have therefore a broader range of choices. However, the gendered division of labour within families can no longer be conceptualized as a "gain", but rather as a constraint to families' economic prospects and consequently to women's (and men's) well-being. In an era of growing deregulation of labour markets and precarious employment relations, gender role specialization is no longer an optimal family strategy. As a result, women's economic autonomy might have opposite effects. On the one hand, it provides women with the option to postpone or avoid entering a conjugal union, particularly if they perceive asymmetrical gender relations as a high cost. On the other hand, women's earning capacity has become a precondition for setting up a new household and could hence speed up the process of union formation.

In the Southern European context, rapid social and economic transformations since the mid-1970s and expanding women's autonomy have resulted in a retreat from marriage and the emergence, albeit slow, of cohabitation. Women with higher education, employment and experience of independent living have led these trends. However, the documented changes across generations indicate that the factors that deter or encourage marriage and cohabitation are not fixed but bound to change. For instance, women's employment has evolved from deterring to facilitating union formation. Future trends in marriage and cohabitation in Southern Europe will be partly conditioned by the adaptation of gender relations within partnerships to the economic role of women, which, though relatively new, is increasingly recognized as crucial to families' well-being.

\section{Acknowledgements}

The authors would like to thank all members of the research network "Gendering European Family Dynamics" coordinated by Livia Sz. Oláh, as well as Elizabeth Thomson and two anonymous referees of Demographic Research, for their valuable 
comments and suggestions. This research was partially financed by the project "Families formed outside marriage: A socio-demographic analysis of the weakening linkages between sex, partnership, marriage and childbearing”, Spanish Ministry of Education and Science (Ref. SEJ2006-03485). Financial support for network meetings from the Swedish Council for Working Life and Social Research (FAS) via de Swedish Institute for Future Studies is also gratefully acknowledged. 


\section{References}

Ahn, N. and Mira, P. (2001). Job bust, baby bust: Evidence from Spain. Journal of Population Economics 14(3): 505-521.

Allison, P.D. (1984). Event history analysis: Regression for longitudinal event data. Beverly Hills: Sage. (Sage university papers: Series quantitative applications in the social sciences ; 07-046)

Almeida, A.N. and Wall, K. (2001). Família e quotidiano: movimentos e sinais de mudança. In: Brito, J.M. Brandão de (ed.). O País em revolução. Lisboa: Notícias: 277-307.

Aassve, A., Billari, F.C., Mazzuco, S. and Ongaro, F. (2002). Leaving home: A comparative analysis of ECHP data. Journal of European Social Policy 12(4): 259-276.

Baizán, P., Michielin, F. and Billari, F. (2002). Political economy and life course patterns: The heterogeneity of occupational, family and household trajectories of young Spaniards. Demographic Research 6(8): 189-240. http://www.demographic-research.org/volumes/vol6/8/

Batalova, J. and Cohen, P.N. (2002). Premarital cohabitation and housework: Couples in cross-national perspective. Journal of Marriage and the Family 64(3): 129144.

Baxter, J. (2005). To marry or not to marry: Marital status and the household division of labour. Journal of Family Issues 26(3): 300-321.

Becker, G. (1981). A treatise on the family. Cambridge: Harvard University Press.

Bermeo, N. (2001). Unemployment in the new Europe. New York: Cambridge University Press.

Berrington, A. and Diamond, I. (2000). Marriage or cohabitation: A competing risks analysis of first partnership formation among the 1958 British cohort. Journal of the Royal Statistical Society: Series A -Statistics in Society 163(2): 127-151.

Billari, F. (2005). Partnership, childbearing and parenting: Trends of the 1990s. In: Macura, M., MacDonald, A. and Haug, W. (eds.). The new demographic regime: Population challenges and policy responses. New York: United Nations: 63-94.

Billari, F., Castiglioni, M., Castro Martín, T., Michielin, F. and Ongaro, F. (2002). Household and union formation in a Mediterranean fashion: Italy and Spain. In: Klijzing, E. and Corijn, M. (eds.). Dynamics of fertility and partnership in 
Europe:Iinsights and lessons from comparative research; Volume 2. New York: United Nations: 17-41.

Billari, F.C., Philipov, D. and Baizán, P. (2001). Leaving home in Europe: The experience of cohorts born around 1960. International Journal of Population Geography 7: 339-356.

Billari, F. and Wilson, C. (2001). Convergence towards diversity? Cohort dynamics in the transition to adulthood in contemporary Western Europe. MPIDR Working Paper WP 2001-039. Rostock: Max Planck Institute for Demographic Research. http://www.demogr.mpg.de/Papers/Working/WP-2001-039.pdf

Blossfeld, H.-P. (2003). Globalization, social inequality and the role of country-specific institutions. In: Conceição, P., Heitor, M.V. and Lundvall, B.A. (eds.). Innovation, competence building and social cohesion in Europe: Towards a learning society. Cheltenham: Edward Elgar: 303-324.

Blossfeld, H.-P. and Huinink, J. (1991). Human capital investments or norms of role transition? How women's schooling and career affect the process of family formation. American Journal of Sociology 97(1): 143-168.

Bracher, M. and Santow, G. (1998). Economic independence and union formation in Sweden. Population Studies 52(3): 275-294.

Castro-Martín, T., Domínguez-Folgueras, M. and Martín-García, T. (2008). Not truly partnerless: Non-residential partnerships and retreat from marriage in Spain. Demographic Research 18(16): 443-468. http://www.demographicresearch.org/Volumes/Vol18/16/

Cherlin, A. (2000). Toward a new home socioeconomics on union formation. In: Waite, L.J. (ed.). The ties that bind: Perspectives on marriage and cohabitation. New York: Aldine de Gruyter: 126-144.

Chesnais, J.C. (1996). Fertility, family and social policy in contemporary Western Europe. Population and Development Review 22(4): 729-739.

Clarkberg, M., Stolzberg, R. and White, L. (1995). Attitudes, values and entrance into cohabitational versus marital unions. Social Forces 74(2): 609-634.

Coppola, N. (2004). Education and union formation as simultaneous processes in Italy and Spain. European Journal of Population 20(3): 219-250.

Cunningham, M. (2005). Gender in cohabitation and marriage: The influence of gender ideology on housework allocation over the life course. Journal of Family Issues 26(8): 1037-1061. 
Dalla Zuanna, G. and Micheli, G.A. (2004). Strong family and low fertility: A paradox? New perspectives in interpreting contemporary family and reproductive behaviour. Dordrecht: Kluwer Academic Publishing.

Esping-Andersen, G. (1999). Social foundations of postindustrial economies. Oxford: Oxford University Press.

Fernández Cordón, J.A. (1997). Youth residential independence and autonomy: A comparative study. Journal of Family Issues 18(6): 576-607.

Fernández Cordón, J.A. and Sgritta, G. (2000). The southern European paradox. Paper presented at the annual seminar of the European Observatory on the Social Situation, Demography and Family "Low Fertility, Families and Public Policies", Sevilla, 15-16 September 2000.

Goldscheider, F.K. and Waite, L.J. (1987). Nest-leaving patterns and the transition to marriage for young men and women. Journal of Marriage and the Family 49(3): 507-516.

Goldscheider, F., Turcotte, P. and Kopp, A. (2001). The changing determinants of women's first union formation in industrialized countries: The United States, Canada, Italy and Sweden. Genus 57(3-4): 107-134.

Goldstein, J.R. and Kenny, C.T. (2001). Marriage delayed or marriage forgone? New cohort forecasts of first marriage for U.S. women. American Sociological Review 66(4): 506-519.

Golsch, K. (2003). Employment flexibility in Spain and its impact on transitions to adulthood. Work, Employment \& Society 17(4): 691-718.

González, M.J. (2000). Partnership formation in the context of women's growing educational attainment. Papers de Demografía 180. Barcelona: Centre d'Estudis Demogràfics: 43 p. http://www.ced.uab.es/publicacions/PapersPDF/Text180.pdf

González, M.J., Miret, P. and Treviño, R. (2006). Relationships in a constant trial: Is cohabitation the best choice for achieving gender equality? Paper presented at the European Population Conference, Liverpool, 21-24 June 2006.

Heuveline, P. and Timberlake, J.M. (2004). The role of cohabitation in family formation: The United States in comparative perspective. Journal of Marriage and the Family 66(5): 1214-1230.

Hoem, J. (1986). The impact of education on modern family-union initiation. European Journal of Population 2(2): 113-133. 
Holdsworth, C. (2005). When are the children going to leave home!: Family culture and delayed transitions in Spain. European Societies 7(4): 547-566.

Holdsworth, C. and Irazoqui, M. (2002). First housing moves in Spain: An analysis of leaving home and first housing acquisition. European Journal of Population 18(1): 1-19.

Jurado Guerrero, T. and Naldini, M. (1996). Is the South so different? Italian and Spanish families in comparative perspective. Southern European Society \& Politics 1(3): 42-66.

Kaufman, G. (2000). Do gender role attitudes matter? Family formation and dissolution among traditional and egalitarian men and women. Journal of Family Issues 21(1): 128-144.

Kiernan, K. (2000a). Cohabitation in Western Europe: Trends, issues and implications. In: Booth, A. and Landale, N. (eds.). Just living together: Implications of cohabitation on families, children and social policy. Mahwah: Lawrence Erlbaum Associates.

Kiernan, K. (2000b). European perspectives on union formation. In: Waite, L.J. (ed.). The ties that bind: Perspectives on marriage and cohabitation. New York: Aldine de Gruyter: 40-58.

Kohler, H., Billari, F. and Ortega, J.A. (2002). The emergence of lowest-low fertility in Europe during the 1990s. Population and Development Review 28(6): 641-680.

Lesthaeghe, R. and Meekers, D. (1986). Value changes and the dimensions of familism in the European community. European Journal of Population 2(3-4): 225-268.

Liefbroer, A.C. and Corijn, M. (1999). Who, what, where, and when? Specifying the impact of educational attainment and labour force participation on family formation. European Journal of Population 15(1): 45-75.

Luxán, M., Miret, P. and Treviño, R. (1998). Is the male provider model still in place? Partnership formation in contemporary Spain. In: González, M.J., Jurado, T. and Naldini, M. (eds.). Gender inequalities in southern Europe: Women, work and welfare in the 1990s. London: Frank Cass: 171-194.

Mason, K.O. (1974). Women's labor force participation and fertility. Research Triangle Park: Center for Population Research and Services, Research Triangle Institute.

McDonald, P. (2000). Gender equity, social institutions and the future of fertility. Journal of Population Research 17(1): 1-16. 
Meil Landwerlin, G. (2003). Las uniones de hecho en España. Madrid: Centro de Investigaciones Sociológicas.

Moors, G. (2000). Values and living arrangements: A recursive relationship. In: Waite, L. (ed.). The ties that bind: Perspectives on marriage and cohabitation. New York: Aldine de Gruyter: 212-226.

Ono, H. (2003). Women's economic standing, marriage timing and cross-national contexts of gender. Journal of Marriage and the Family 65(2): 275-286.

Oppenheimer, V.K. (1994). Women's rising employment and the future of the family in industrial societies. Population and Development Review 20(2): 293-342.

Oppenheimer, V.K. and Lew, V. (1995). American marriage formation in the 1980s: How important was women's economic independence? In: Mason, K.O. and Jensen, A.M. (eds.). Gender and family change in industrialized countries. Oxford: Clarendon Press: 105-138.

Pfau-Effinger, B. (2003). Changing welfare states and labour markets in the context of European gender arrangements. COST A13 "Changing Labour Markets, Welfare Policies and Citizenship" Working Paper. http://www.socsci.auc.dk/cost/gender/Workingpapers/pfaueffinger.pdf

Presser, H.B. (1971). The timing of the first birth, female roles, and black fertility. Milbank Memorial Fund Quarterly 49: 329-361.

Raymo, J.M. (2003). Educational attainment and the transition to first marriage among Japanese women. Demography 40(1): 83-103.

Raymo, J. and Iwasawa, M. (2005). Marriage market mismatches in Japan: An alternative view of the relationship between women's education and marriage. American Sociological Review 70(5): 801-822.

Reher, D. (1998). Family ties in western Europe: Persistent contrasts. Population and Development Review 24(2): 203-234.

Rosina, A. and Fabroni, R. (2004). Is marriage loosing its centrality in Italy? Demographic Research 11(6): 149-172. http://www.demographicresearch.org/volumes/vol11/6/

Santow, G. and Bracher, M. (1994). Change and continuity in the formation of first marital unions in Australia. Population Studies 48(3): 475-496.

Simó, C., Castro Martín, T. and Soro Bonmatí, A. (2005). The Spanish case: The effects of the globalization process on the transition to adulthood. In: Blossfeld 
H.P., Klijzing E., Mills M. and Kurz K. (eds.). Globalization, uncertainty and youth in society. London: Routledge: 375-402.

Sweeney, M. (2002). Two decades of family change: The shifting economic foundations of marriage. American Sociological Review 67(1): 132-147.

Sweeney, M. and Cancian, M. (2004). The changing importance of white women's economic prospects for assortative mating. Journal of Marriage and Family 66(4): 1038-1041.

Thornton, A., Axinn, W.G. and Teachman, J.D. (1995). The influence of school enrolment and accumulation on cohabitation and marriage in early adulthood. American Sociological Review 60(5): 762-774.

Tobío, C. (2001). Marriage, cohabitation and the residential independence of young people in Spain. International Journal of Law, Policy and the Family 15(1): 6887.

Trifiletti, R. (1999). Southern European welfare regimes and the worsening position of women. Journal of European Social Policy 9(1): 49-64.

Van de Kaa, D. (1987). Europe's second demographic transition. Population Bulletin 42(1).

Xie, Y., Raymo, J.M., Goyette, K. and Thornton, A. (2003). Economic potential and entry into marriage or cohabitation. Demography 40(2): 351-367. 


\section{Appendix}

\section{Table A1: Odds Ratios from multinomial logistic regression on men's entry into marriage and cohabitation, Spain and Portugal}

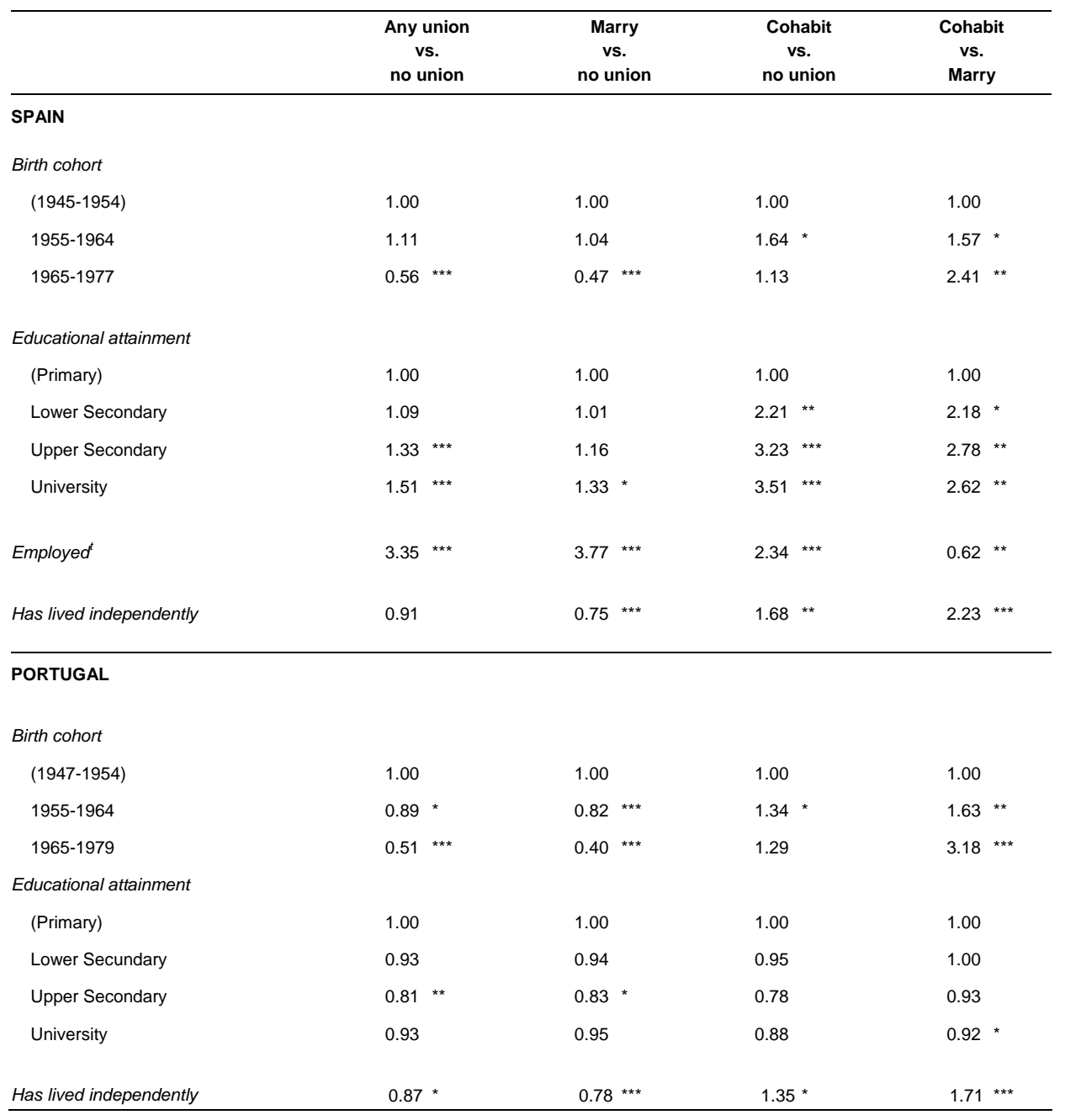

$\mathrm{p}<.05,{ }^{* *} \mathrm{p}<.01,{ }^{* * *} \mathrm{p}<.001$

t time-varying covariate.

Notes: The models control for school enrollment, fertility status, number of siblings and parental separation. The information collected by Portugal FFS does not allow to construct a time-varying covariate for employment, and most men in the sample have some working experience. Hence, in contrast to women's models, the variable "ever worked" is not included in men's models. 
Domínguez-Folgueras \& Castro-Martín: Women’s changing socioeconomic position and union formation

Table A2: Changing effect of education, employment and independent living by birth cohort on women's entry into marriage and cohabitation, Spain and Portugal

\begin{tabular}{|c|c|c|c|c|c|c|c|c|c|}
\hline \multirow{2}{*}{$\begin{array}{l} \\
\text { SPAIN }\end{array}$} & & \multicolumn{2}{|c|}{$\begin{array}{l}\text { Any union } \\
\text { vs. } \\
\text { no union }\end{array}$} & \multicolumn{2}{|c|}{$\begin{array}{c}\text { Marry } \\
\text { Vs. } \\
\text { no union }\end{array}$} & \multicolumn{2}{|c|}{$\begin{array}{c}\text { Cohabit } \\
\text { Vs. } \\
\text { no union }\end{array}$} & \multicolumn{2}{|c|}{$\begin{array}{l}\text { Cohabit } \\
\text { Vs. } \\
\text { Marry }\end{array}$} \\
\hline & & & & & & & & & \\
\hline \multicolumn{10}{|c|}{ Education and birth cohort } \\
\hline (Primary) & & 1.00 & & 1.00 & & 1.00 & & 1.00 & \\
\hline \multirow[t]{3}{*}{ Lower Secundary } & $1945-1954$ & 0.97 & & 0.98 & & 0.94 & & 0.96 & \\
\hline & $1655-1964$ & 1.04 & & 1.02 & & 1.44 & & 1.40 & \\
\hline & 1965-1979 & 0.70 & $\star \star \star \star ~$ & 0.58 & $\star \star \star$ & 3.48 & $\star \star \star$ & 6.00 & 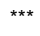 \\
\hline \multirow[t]{3}{*}{ Upper Secondary } & $1945-1954$ & 0.78 & * & 0.75 & * & 1.68 & & 2.23 & \\
\hline & $1655-1964$ & 0.93 & & 0.87 & ** & 2.33 & ** & 2.66 & ** \\
\hline & $1965-1979$ & 0.41 & $* \star \star$ & 0.32 & $\star \star \star$ & 2.30 & $\star \star \star \star$ & 7.17 & $* \star \star$ \\
\hline \multirow[t]{3}{*}{ University } & $1945-1954$ & 0.99 & & 0.95 & & 2.11 & * & 2.21 & * \\
\hline & $1655-1964$ & 1.04 & & 0.98 & & 2.43 & 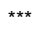 & 2.48 & $\star \star$ \\
\hline & $1965-1979$ & 0.40 & 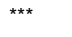 & 0.29 & $\star \star \star$ & 2.49 & $\star \star \star$ & 8.59 & 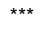 \\
\hline \multicolumn{10}{|c|}{ Employment and birth cohort } \\
\hline (Not working) & & 1.00 & & 1.00 & & 1.00 & & 1.00 & \\
\hline \multirow[t]{3}{*}{ Working } & $1945-1954$ & 0.96 & & 1.01 & & 0.60 & & 0.59 & \\
\hline & $1655-1964$ & 1.44 & $* \star *$ & 1.49 & $* \star \star$ & 1.09 & & 0.73 & \\
\hline & 1965-1979 & 1.17 & * & 0.99 & & 2.57 & $\star \star \star$ & 2.59 & *** \\
\hline \multicolumn{10}{|c|}{ Independent living and birth cohort } \\
\hline \multicolumn{2}{|c|}{ (Has not lived independently) } & 1.00 & & 1.00 & & 1.00 & & 1.00 & \\
\hline \multirow[t]{3}{*}{ Lived independently } & $1945-1954$ & 0.86 & & 0.81 & * & 1.76 & * & 2.17 & * \\
\hline & $1655-1964$ & 0.93 & & 0.71 & $\star \star \star *$ & 3.10 & $\star \star \star \star ~$ & 4.35 & *** \\
\hline & $1965-1979$ & 0.96 & & 0.42 & $\star \star \star \star ~$ & 5.41 & $\star \star \star \star ~$ & 12.73 & 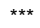 \\
\hline
\end{tabular}


Table A2: (continued)

\begin{tabular}{|c|c|c|c|c|c|c|c|c|c|}
\hline & & $\begin{array}{c}\text { Any } \\
\text { union vs. } \\
\text { no union }\end{array}$ & & $\begin{array}{c}\text { Marry } \\
\text { vs. } \\
\text { no union }\end{array}$ & & $\begin{array}{c}\text { Cohabit } \\
\text { vs. } \\
\text { no union }\end{array}$ & & $\begin{array}{c}\text { Cohabit } \\
\text { vs. } \\
\text { marry }\end{array}$ & \\
\hline \multicolumn{10}{|l|}{ PORTUGAL } \\
\hline \multicolumn{10}{|l|}{ Education and birth cohort } \\
\hline & & 1.00 & & 1.00 & & 1.00 & & 1.00 & \\
\hline \multirow[t]{3}{*}{ Lower Secundary } & $1945-1954$ & 0.84 & & 0.86 & 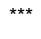 & 0.65 & & 0.75 & \\
\hline & $1655-1964$ & 1.05 & & 1.12 & $* \star \star$ & 0.79 & & 0.71 & \\
\hline & $1965-1979$ & 5.92 & 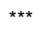 & 6.78 & 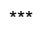 & 2.16 & 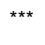 & 0.31 & *** \\
\hline \multirow[t]{3}{*}{ Upper Secondary } & 1945-1954 & 0.88 & & 1.03 & *** & $\ldots$ & & $\ldots$ & \\
\hline & $1655-1964$ & 0.75 & & 0.88 & 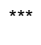 & 0.31 & & 0.35 & \\
\hline & $1965-1979$ & 9.32 & $\star \star \star$ & 11.07 & $\star \star \star *$ & 1.46 & & 0.13 & *** \\
\hline \multirow[t]{3}{*}{ University } & $1945-1954$ & 1.13 & & 1.41 & & 0.38 & & 0.26 & \\
\hline & $1655-1964$ & 0.99 & & 0.73 & & 1.20 & & 1.64 & \\
\hline & 1965-1979 & 3.61 & $\star \star \star ~$ & 4.34 & $\star \star \star ~$ & 0.56 & & 0.13 & *** \\
\hline \multicolumn{10}{|l|}{ Employment and birth cohort } \\
\hline (Not working) & & 1.00 & & 1.00 & & 1.00 & & 1.00 & \\
\hline \multirow[t]{3}{*}{ Working } & $1945-1954$ & 0.70 & $\star \star \star *$ & 0.70 & *** & 0.72 & * & 1.03 & \\
\hline & $1655-1964$ & 0.74 & $\star * \star$ & 0.68 & $\star * \star$ & 1.17 & & 1.71 & $\star * \star$ \\
\hline & $1965-1979$ & 1.14 & * & 1.02 & & 2.00 & 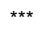 & 1.94 & *** \\
\hline \multicolumn{10}{|l|}{$\begin{array}{l}\text { Independent living and birth } \\
\text { cohort }\end{array}$} \\
\hline \multicolumn{2}{|c|}{ (Has not lived independently) } & 1.00 & & 1.00 & & 1.00 & & 1.00 & \\
\hline \multirow[t]{3}{*}{ Lived independently } & 1945-1954 & 0.54 & $\star \star \star *$ & 0.51 & 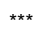 & 0.68 & * & 1.31 & \\
\hline & $1655-1964$ & 0.42 & $\star \star \star ~$ & 0.32 & $\star * \star$ & 1.22 & & 3.79 & 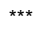 \\
\hline & $1965-1979$ & 0.80 & & 0.63 & $\star *$ & 2.50 & $* * *$ & 3.96 & $\star * *$ \\
\hline
\end{tabular}

${ }^{\star} p<.05,{ }^{* \star} p<.01,{ }^{* \star *} p<.001$

Notes: Reference categories in parentheses.

The models control for school enrollment, fertility status, number of siblings and parental separation. 
Domínguez-Folgueras \& Castro-Martín: Women’s changing socioeconomic position and union formation 